\title{
Implementasi Metode MD5 dan QR Code Untuk Pembuatan ID Card Dosen Dan Karyawan Fakultas Teknik Di Universitas Muhammadiyah Bengkulu
}

\author{
Muhammad Husni Rifqo1, Firmansyah 2 \\ 1,2Program Studi Informatika, Fakultas Teknik, Universitas Muhammadiyah Bengkulu \\ Jl. Bali PO BOX 118. Telp (0736) 227665, Fax (0736) 26161, Bengkulu 38119 \\ Imhrifqo@umb.ac.id; 2firmansampoerna70@gmail.com
}

\begin{abstract}
The development of information technology is increasing, the information technology community life almost cover all of the fields included in the company or educational institution. Even is a necessity for the company or educational institution will be the availability of information has been computerized. Almost all companies today use identity cards (ID Card) on employees as the identity that differentiates it from other companies, many of the benefits of the use of ID card system that is integrated with the attendance and the company's database. Because it can improve the motivation and performance of employees. But we very rarely found the use of the ID card on higher education, especially in the area of Bengkulu province, whatever because there is no ID card or an existing but still reluctant to wear them. Expectations from the manufacture of ID Card that uses a QR Code can be attracted to use them, especially in the engineering faculty of Muhammadiyah University of Bengkulu. Making the ID Card using the tools Delphi 7 and is integrated with microsoft acces to a database which is expected to be used for the attendance system. Then using MD5 as the security of the ID card that are not easily counterfeited. The author chose QR Code because in it can store information so that all data can be kept confidential. In the future it would be better if used with the attendance system that still uses the fingerprint system. Expectations from the manufacture of ID Card that uses a QR Code can be attracted to use them, especially in the engineering faculty of Muhammadiyah University of Bengkulu. Making the ID Card using the tools Delphi 7 and is integrated with microsoft acces to a database which is expected to be used for the attendance system. Then using MD5 as the security of the ID card that are not easily counterfeited. The author chose QR Code because in it can store information so that all data can be kept confidential. In the future it would be better if used with the attendance system that still uses the fingerprint system.
\end{abstract}

Keywords; Id card, QR code, MD5, UMB

Abstrak -- Perkembangan teknologi informasi saat ini semakin meningkat, dalam kehidupan masyarakat teknologi informasi hampir mencakup kesemua bidang termasuk kedalam perusahaan atau instansi pendidikan. Bahkan merupakan suatu keharusan bagi perusahaan atau instansi pendidikan akan ketersediaan informasi yang sudah terkomputerisasi. Hampir semua perusahaan sekarang ini menggunakan kartu identitas (ID Card) pada pegawainya sebagai identitas yang membedakan dengan perusahaan yang lain, banyak keuntungan yang didapat dari pemakaian sistem ID Card yang terintegrasi dengan absensi dan database perusahaan. Karena hal ini dapat meningkatkan motifasi dan kinerja pegawai. Akan tetapi kita sangat jarang menemukan pemakaian ID Card pada perguruan tinggi khususnya di daerah Provinsi Bengkulu, entah apa karena belum ada ID Card atau sudah ada tapi masih enggan untuk memakainya. Harapan dari pembuatan ID Card yang menggunakan $Q R$ Code ini dapat menarik minat untuk menggunakannya khususnya di fakultas teknik Universitas Muhammadiyah Bengkulu. Pembuatan ID Card ini menggunakan tools Delphi 7 dan terintegrasi dengan microsoft acces sebagai database yang nantinya diharapkan bisa digunakan untuk sistem absensi. Kemudian menggunakan metode MD5 sebagai pengamanan dari ID Card agar tidak mudah dipalsukan. Penulis memilih $Q R$ Code karena didalamnya bisa menyimpan informasi sehingga semua data bisa dirahasiakan. Kedepan akan lebih baik jika digunakan bersama sistem absensi yang selama ini masih menggunakan sistem sidik jari.

Kata Kunci: Id card, QR code, MD5, UMB

\section{PENDAHULUAN}

Perkembangan teknologi yang sangat pesat sekarang ini tentulah berpengaruh pada kemudahan yang diberikan dalam kehidupan manusia terutama dalam bidang pemerintahan, perusahaan, pendidikan dari tingkat bawah sampai ke tingkat universitas. Dalam sebuah perusahaan atau instansi pendidikan dimana sekarang ini ID Card menjadi bagian penting sebagai pengenal atau bahkan sebagai atribut yang wajib digunakan. Ketika semua karyawan menggunakan kartu ini maka kesan yang muncul 
adalah hal yang positif dan suasana formal akan mewarnai tempat kerja. Akan tetapi data atau informasi penting yang sifatnya rahasia hanya boleh diakses oleh orang tertentu saja, untuk berbagai alas an keamanan data atau informasi merupakan asset berharga yang harus dilindungi [1].

Pada saat ini sudah banyak ID Card yang menggunakan sistem magnetik atau Quick Response Code ( $Q R$ Code) yang dapat difungsikan sebagai kartu identitas bahkan absensi sekalipun. $Q R$ Code adalah [2] semacam simbol dua dimensi yang dikembangkan oleh Denso Wave yang merupakan anak perusahaan dari Toyota sebuah perusahaan Jepang pada tahun 1994. QR Code memiliki kapasitas tinggi dalam pengkodean data, yaitu mampu menyimpan semua jenis data, seperti data numerik, alphanumerik, kode biner dan huruf kanji. Secara spesifik $Q R$ Code mampu menyimpan data jenis numerik sampai dengan 7.089 karakter, data alphanumerik sampai dengan 4.296 karakter, kode binari sampai dengan 2.844 byte, dan huruf kanji sampai dengan 1.817 karakter.

Dosen dan karyawan fakultas teknik Universitas Muhammadiyah Bengkulu merupakan bagian dari kesatuan institusi atau lembaga pendidikan yang ada di Universitas Muhammadiyah Bengkulu. Saat ini baik dosen ataupun karyawan tidak memiliki tanda pengenal (ID Card) yang baik dan terenkripsi, hal ini dilihat kurang rapi dan tidak formal, sedangkan seorang dosen dan karyawan haruslah berpakaian rapi dan formal karena mereka menjadi contoh atau tauladan bagi mahasiswanya.

Perancangan ID Card yang terenkripsi dimaksudkan untuk menjaga keamanan data dosen dan karyawan agar tidak mudah disalah gunakan. Berkembangnya teknologi dan kebutuhan manusia yang semakin meningkat dapat dimanfaatkan untuk menciptakan suatu teknologi yang dapat menciptakan keamanan [3]. Dalam perkembangannya, bukan hanya informasi yang menjadi penting, tetapi perkembangan teknologi pun menjadi hal yang sangat penting khususnya teknologi keamanan komputer [4].

Dari pembahasan diatas terdapat permasalahan pada pembuatan $Q R$ code yaitu penyandian dari informasi asli (plain text) menjadi chiper text atau $Q R$ Code yang sudah berisi informasi yang dirahasiakan. Untuk menghasilkan suatu chiper text terdapat beberapa cara, salah satunya adalah dengan menggunakan fungsi hash satu arah. MD5 adalah salah satu metode hash satu arah yang bisa digunakan dalam penelitian ini. Algoritma MD5 adalah algoritma fungsi hash yang dikembangkan oleh Ronald L. Rivest pada tahun 1992. Algoritma MD5 dapat melakukan hashing pada pesan dengan panjang sembarang (arbitrary) menjadi message digest dengan panjang tetap (fix) sepanjang 128 bit [5].

Perancangan ID Card yang terenkripsi ini nantinya akan diuji cobakan kepada dosen dan karyawan fakultas teknik Universitas Muhammadiyah Bengkulu.

\section{LANDASAN TEORI}

A. Implementasi

Implementasi adalah proses untuk memastikan terlaksananya sutu kebujakan dan tercapainya kebijakan tersebut [6]. Sedangkan menurut Kamus Besar Bahasa Indonesia, implementasi adalah pelaksanaan dan penerapan, dimana kedua hal ini bermaksud untuk mencari bentuk tentang hal yang disepakati terlebih dahulu.

Dapat disimpulkan bahwa implementasi adalah kegiatan pelaksanaan dan penerapan dari suatu kebijakan yang sudah disepakati sebelumnya.

B. Message Digest (MD5)

Fungsi hash yang sering digunakan dalam kriptografi adalah MD5, MD5 adalah salah satu dari serangkaian algoritma Message Digest yang didesain oleh Professor Ronald Rivest dari MIT.

MD5 merupakan perbaikan dari MD4 setelah MD4 diserang oleh kriptanalis. Algoritma MD5 menerima masukan berupa pesan dengan ukuran sembarang dan menghasilkan message digest yang panjangnya 128 bit [7]. MD5 tidak memiliki sistim pengamanan seperti persamaan matematika, namun untuk setiap fungsi hash $h$, domain $\mathrm{D}$ dan range $\mathrm{R}$ membutuhkan tiga hal berikut [8]:

1. Pre Image Resistance : jika diberi suatu nilai y $\varepsilon \mathrm{R}$, maka kita tidak akan dapat mencari suatu nilai $\mathrm{x} \varepsilon \mathrm{D}$ dimana $\mathrm{h}(\mathrm{x})=\mathrm{y}$.

2. Second Pre Image Resistance : jika diberi suatu nilai $\mathrm{x} \varepsilon \mathrm{D}$, maka kita tidak akan dapat mencari nilai $x^{\prime} \varepsilon \mathrm{D}$ dimana $\mathrm{h}(\mathrm{x})=\mathrm{h}\left(\mathrm{x}^{\prime}\right)$.

3. Collision Resistance : kita tidak akan dapat mencari nilai $\mathrm{x}, \mathrm{x}$ ' $\varepsilon \mathrm{D}$ dimana $\mathrm{h}(\mathrm{x})=\mathrm{h}\left(\mathrm{x}^{\prime}\right)$.

\section{QR Code}

Kode QR atau biasa dikenal dengan $Q R$ Code adalah bentuk evolusi kode batang dari satu dimensi menjadi dua dimensi [9]. QR Code dibuat oleh perushaan Jepang, Denso Wave, pada tahun 1994. Tujuan awal dibuatnya QR Code 
adalah untuk menampung huruf kanji dan karakter kana, karena barcode hanya mampu mengodekan alfanumerik.

Tujuan dari $Q R$ Code adalah untuk menyampaikan informasi dengan cepat dan mendapatkan response yang cepat pula, berbeda dengan kode batang, yang hanya menyimpan informasi secara horizontal, $Q R$ code mampu menyimpan informasi secara horizontal dan vertikal, oleh karena itu secara otomatis $Q R$ code dapat menampung informasi yang lebih banyak daripada kode batang. QR code digunakan dalam konteks yang lebih luas, termasuk aplikasi komersial dan kemudahan pelacakan aplikasi berorientasi yang ditujukan untuk pengguna telepon selular maupun PC.

D. ID Card

ID Card adalah singkatan dari identity card yang dalam bahasa Indonesia mempunyai arti sebagai kartu tanda pengenal. Dalam sebuah perusahaan atau instansi pendidikan, ID card rupanya sudah menjadi bagian dari kebutuhan bagi hampir semua perusahaan atau instansi.

\section{METODE PENELITIAN}

A. Metode Pengumpulan Data

Dasar penelitian yang digunakan sebagai bahan untuk kelengkapan data dan informasi adalah:

1. Study Pustaka (Literature Review)

Dengan membaca, mempelajari dan memahami referensi-referensi atau literatur yang berhubungan dengan aplikasi yang akan penulis buat.

2. Observasi

Untuk memperoleh data yang dibutuhkan dalam penelitian ini peneliti melakukan observasi langsung dengan pihak terkait seperti dekan dan para wakil dekan fakultas Teknik Universitas Muhammadiyah Bengkulu.

3. Wawancara

Yaitu dengan mengadakan tanya jawab kepada pihak yang ada hubungannya dengan objek penelitian, dalam hal ini melakukan wawancara dengan beberapa dosen dan karyawan fakultas Teknik Universitas Muhammadiyah Bengkulu.
B. Model Perancangan Sistem

Dalam perancangan ini penulis menggunakan model perancangan incremental, model ini adalah model pengembangan sistem pada software engineering berdasarkan requirement software yang dipecah menjadi beberapa fungsi atau bagian sehingga model pemngabangannya secara bertahap.

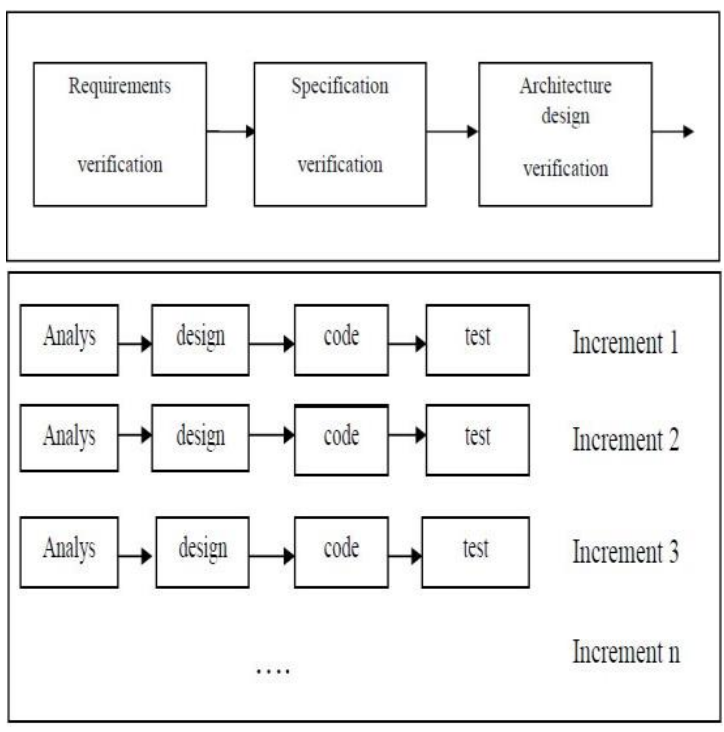

Gambar 3.1 incremental model

Penjelasan gambar diatas sebagai berikut:

1. Requirement adalah proses tahapan awal yang dilakukan pada Incremental model adalah penentuan kebutuhan atau analisis kebutuhan.

2. Specification, adalah proses spesifikasi dimana menggunakan analisis kebutuhan sebagai acuannya.

3. Architecture Design, adalah tahap selanjutnya, perancangan software yang terbuka agar dapat diterapkan sistem pembangunan per-bagian pada tahap selanjutnya.

4. Code, setelah melakukan proses desain selanjutnya ada pengkodean.

5. Test, merupakan tahap pengujian dalam model ini. 
C. Rancangan Sistem

1. Flowchart MD5

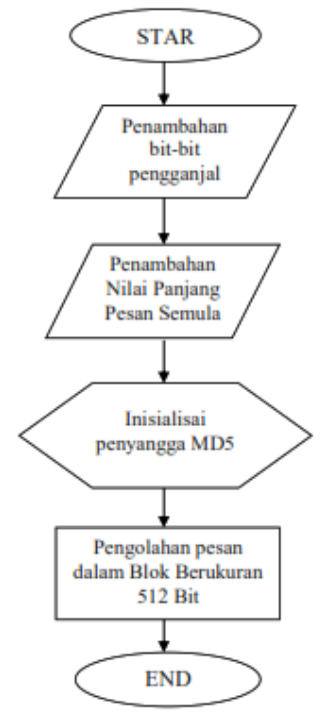

Gambar 3.2 flowchart MD5

Penjelasan dari flowchart diatas adalah sebagai berikut:

a) Setelah memulai pesan ditambahkan dengan sejumlah bit pengganjal sedemikian panjang pesan ( dalam satuan bit ) kongruen dengan 448 modulo 512.

b) Pesan yang telah diberi bit-bit pengganjal selanjutnya ditambah lagi dengan 64 bit yang menyatakan panjang pesan semula.

c) Kemudian MD5 membutukan 4 buah penyangga ( buffer ) yang masing-masing panjangnya 32 bit.

d) Setelah blok 512-bit diproses bersama dengan penyangga MD menjadi keluaran 128-bit

2. Rancangan menu utama

a. Menu login

\section{Logo UMB}

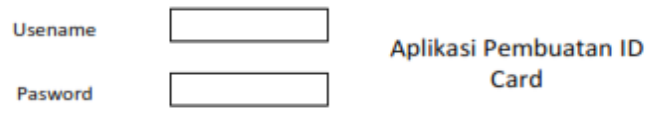

Gambar 3.3 menu login b. Halaman menu utama

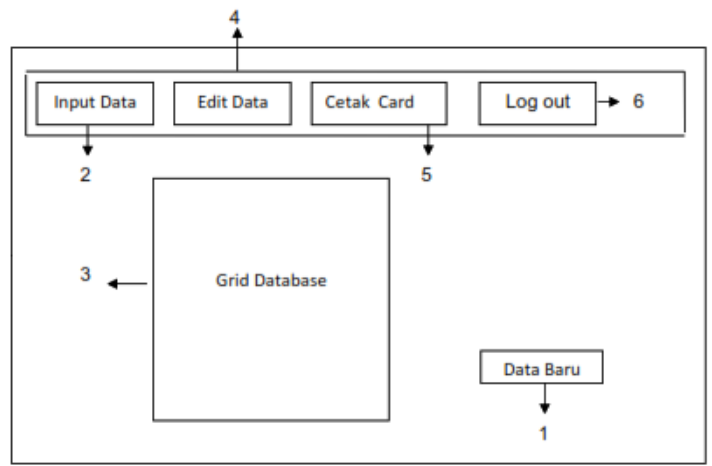

Gambar 3.4 menu utama

c. Halaman input data

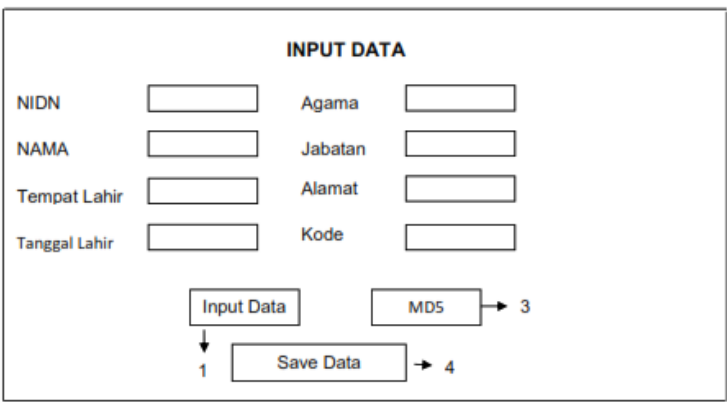

Gambar 3.5 input data

Setelah itu ada dua rancangan yang lain yaitu menu edit data dan menu cetak $I D$ Card

IV. Hasil dan Pembahasan

Dari rancangan sistem dilanjutkan dengan implementasi pembuatan sistem, hasil dari tahapan ini adalah sebagai berikut:

1. Tampilan login

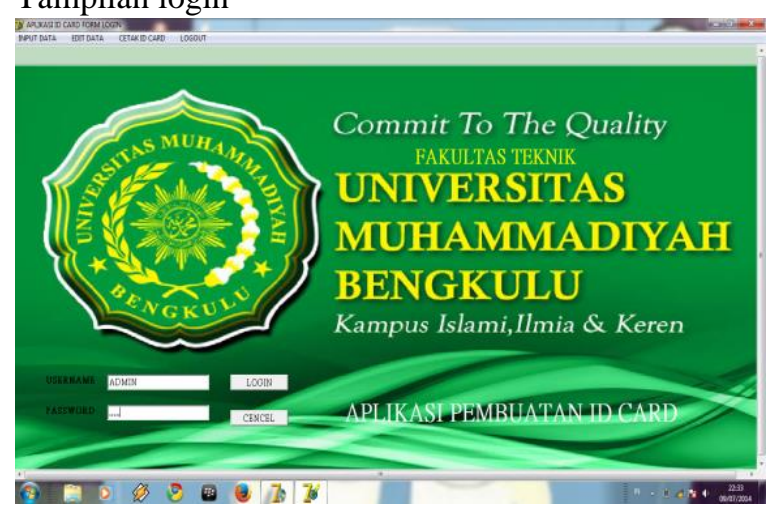

Gambar 4.1 tampilan login

2. Tampilan menu utama

Pada tampilan halaman menu utama terdapat tombol data baru, dan jika di klik akan 
menuju kehalaman input data yang berfungsi untuk menginput data data karyawan, admin juga bisa menggunakan menu yang ada di bagian atas terdiri dari input data, edit data, cetak ID Card dan logout. Dan menu di atas jika di klik akan menuju ke halaman masing masing. Karena halaman menu utama ini merupakan kunci masuk ke semua proses dalam aplikasi ID Card. Dalam tampilan menu utama ini juga terdapat sebuah tabel karyawan yang telah di input untuk membantu admin melihat data karyawan yang telah ada

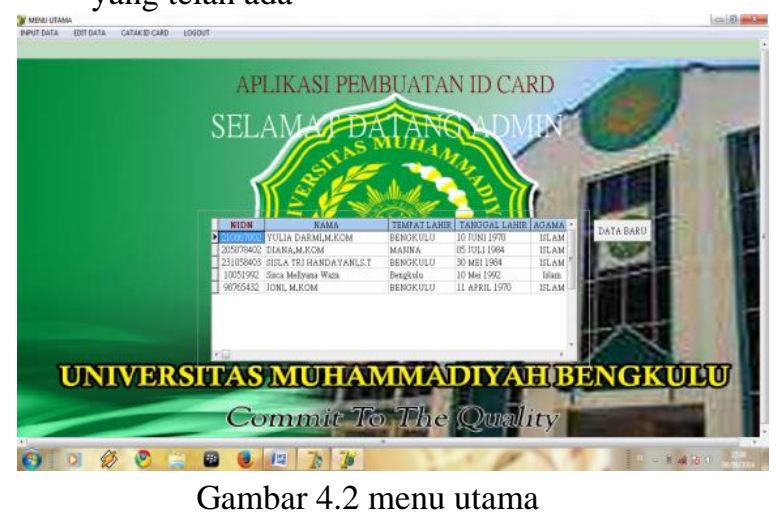

3. Tampilan input data

Pada proses penginputan data tidak hanya biodata karyawan ( NIDN, Nama, Tempat Lahir, Tanggal Lahir, Agama, Alamat dan Jabatan di fakultas teknik UMB ) yang dimasukkan, setelah proses memasukkan data selesai dilanjutkan dengan proses hashing NIDN kedalam MD5. Setelah semua data dimasukkan dan dilakukan proses MD5 baru dilakukan proses memasukkan data dalam $Q R$ Code.

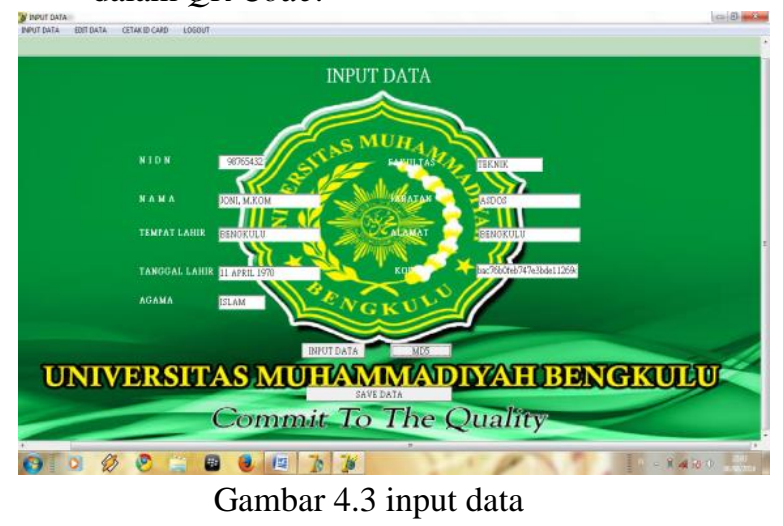

Kemudian ada tampilan edit yang fungsinya untuk merubah data yang salah input, dan terakhir ada tampilan cetak ID Card seperti gambar dibawah ini:

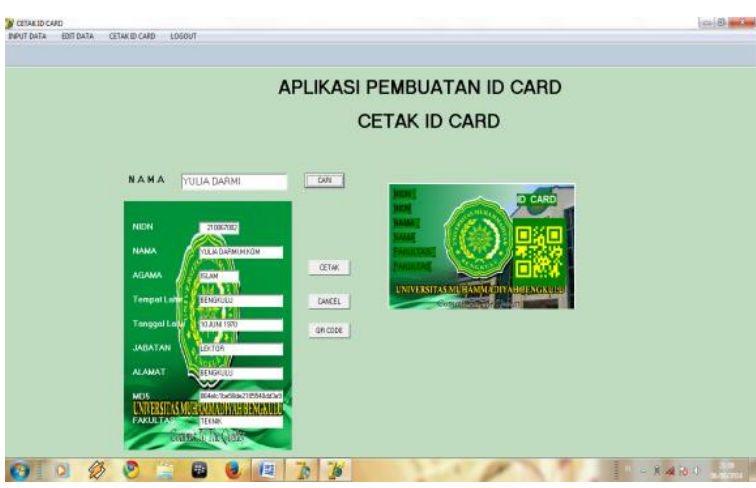

Gambar 4.4 cetak kartu

V. Kesimpulan dan Saran

A. Kesimpulan

Dari hasil penelitian dan pembuatan sistem yang telah penulis lakukan dapat di ambil kesimpulan bahwa pada aplikasi pembuatan ID Card penggunaan $Q R$ Code dan MD5 menggunakan tools Delphi 7 dapat berjalan dengan baik. Penggunaan $Q R$ Code sebagai media penyimpanan data di ID Card sangat menarik sesuai dengan kemajuan Information Technology (IT) dan tuntutan zaman. Serta penggunaan metode MD5 sebagai pengaman ID Card di pandang sangat tepat sebagai pengaman agar data tidak mudah untuk di palsukan.

B. Saran

Dari kesimpulan diatas peneliti memberikan saran untuk menyempurnakan aplikasi pembuatan ID Card dengan mengintegrasikasi beberapa aplikasi yang lain, sehingga pelayanan dan mutu universitas dapat di tingkatkan. Salah satu aplikasi yang perlu di integrasikan adalah absensi dosen dan karyawan di lingkungan Universitas Muhammadiyah Bengkulu.

\section{DAFTAR PUSTAKA}

[1] R. Syahdan and E. Anitasari, "Penggunaan QR Code dengan Enkripsi Vigenere Cipher dalam Pengamanan Data," UNY, Yogyakarta, 2017. 
[2] M. L. Sholeh and L. A. Muharom, "SMART PRESENSI MENGGUNAKAN QR-Code DENGAN ENKRIPSI VIGENERE CIPHER,"

Limits, vol. 13, no. 2, pp. 31-44, 2016.

[3] A. Hidayat, B. Y. M and E. Paulus, "KRIPTOGRAFI HILLCHIPHER

DIGUNAKAN DALAM SISTEM KEAMANAN PADA TIKET DENGAN

TEKNOLOGI QR-CODE," Siliwangi, vol. 3, no. 1, pp. 167-171, 2017.

[4] Y. Apridiansyah and M. H. Rifqo, "APLIKASI KEAMANAN LEMBAR HASIL STUDI MENGGUNAKAN ALGORITMA MESSAGE DIGEST 5 Studi Kasus : Fakultas Teknik Universitas Muhammadiyah Bengkulu," Pseudecode, vol. II, no. 2, pp. 107-114, 2015.

[5] S. C. Nugroho, "Optimized Dictionary Attack on MD5 Algortihm," CITEE 2018, pp. 113-117, 2018.

[6] M. H. Rifqo and A. Wijaya, "IMPLEMENTASI ALGORITMA NAIVE BAYES DALAM PENENTUAN PEMBERIAN KREDIT," Pseudecode, vol. IV, no. 2, pp. 120-128, 2017.

[7] W. Y. Diningrum and M. Hardjianto, "Implementasi One Time Password(OTP) dengan Algoritma Message Digest 5 (MD5) pada Sistem Login E-Learning," Jurnal TICOM, vol. 6, no. 3, pp. 160-164, 2018.

[8] Sumarno, I. Gunawan, H. S. Tambunan and E. Irawan, "ANALISIS KINERJA KOMBINASI ALGORITMA MESSAGE-DIGEST ALGORTIHM 5 (MD5), RIVEST SHAMIR ADLEMAN (RSA ) DAN RIVEST CIPHER 4 (RC4) PADA KEAMANAN E-DOKUMEN," Junal Sistem Informasi Ilmu Komputer Prima, vol. 2, no. 1, pp. 41-48, 2018.

[9] Y. T. Widayati, "APLIKASI TEKNOLOGI QR ( QUICK RESPONSE ) CODE IMPLEMENTASI YANG UNIVERSAL," OMPUTAKI, vol. 3, no. 1, pp. 66-81, 2017. 